\title{
Revisitando o Museu Nacional e a história da Antropologia no Brasil pelas mãos de Heloísa Alberto Torres
}

Adelia Miglievich-Ribeiro²

\section{Resumo}

O artigo destaca o protagonismo de Heloísa Alberto Torres ( 1895-1977) no campo da ciência e da cultura no Brasil, como antropóloga e diretora do Museu Nacional, na cidade do Rio de Janeiro, instituição guardiã dos maiores acervos em História Natural e Antropologia. A análise de sua trajetória permite a reconstrução dos "círculos sociais" (SIMMEL, 1939), em seus entrecruzamentos e tensões, que possibilitaram, na era Vargas, a formação de importantes instituições brasileiras comprometidas com a construção da identidade nacional. Em uma especial "estrutura de sentimentos" (WILLIAMS, 20I I), marcada pelo positivismo e pela indissociabilidade entre progresso científico e soberania nacional, Heloísa Alberto Torres compõe uma geração a valorizar as riquezas naturais e as culturas primordiais como um projeto do campo antropológico em seus inícios. A visibilidade à excepcional trajetória da cientista pretende ainda fazer justiça àquelas mulheres que atuaram

I A pesquisa que subsidia este artigo, fruto da tese de doutorado defendida no PPGSA/IFCS/UFRJ, sob a orientação de Claucia Villas Bôas, no ano 2000, foi por mim publicada bastante posteriormente no liuro Heloísa Alberto Torres e Marina de Vasconcellos: mulheres pioneiras e a formação das Ciências Sociais na cidade do Rio de Janeiro (Ed. UFRJ, 2015), que conjugou o "garimpo" em diversos arquivos no Estado do Rio de Janeiro, além do recurso às narrativas orais. A "tragédia anunciada" do Museu Nacional, seu incêndio em 02 de setembro de 2018, levou-me a revisitá-la criticamente, anunciando novos viezes analíticos a fim de visibilizar a luta, no caso, de uma mulher, que expressa, talvez, o imenso voluntarismo dos e das cientistas cientistas brasileiros(as) em face da diversidade dos obstáculos enfrentados em distintos tempos históricos.

2 Doutora em Sociologia (PPGSA-IFCS-UFRJ). Professora Adjunta do Departamento de Ciências Sociais da Universidade Federal do Espírito Santo (Ufes) e docente permanente no PPG de Ciências Sociais e no PPG de Letras (mestrado e doutorado). PQ Produtividade, nivel 2, do CNPq. Atualmente, em posdoc, como pesquisadora colaboradora do PPGSOL-UnB. E.mail:miglievich@pq.cnpq.br. Commons. Com essa licença você pode compartilhar, adaptar, para qualquer fim, desde que atribua a autoria da obra, forneça um link para a licença, e indicar se foram feitas alterações. 
na ciência e na vida pública, em cargos de mando, em um tempo em que tais arenas ainda eram exclusivamente masculinas. Por fim, conclui-se pela prevalência da dinâmica da vida social e das transformações históricas sobre a aparência de imobilismo das instituições de modo que, mesmo em cenários os mais hostis, é possível identificar as emergências que mantêm viva a esperança.

Palavras-chave: Heloísa Alberto Torres. Museu Nacional. história da Antropologia.

\section{Apresentação}

Aquela "presença de Heloísa" que Carlos Drummond de Andrade tão bem definiu é, contraditoriamente, um imenso vazio para os que, como nós, lidaram de perto com a dileta filha de Alberto Torres. A triste evocação da mestra, em diferentes atividades a que emprestou sua inteligência e seu aplomb, só agora proporcionará triste e dolorosa avaliação.

(POURCHET, 1977, p. 60).

Heloísa Alberto Torres (1895-1977), nas palavras da antropóloga Maria Júlia Pourchet (1977), foi arqueóloga, antropóloga, indigenista, pesquisadora, chefe, membro de diferentes conselhos científicos. Uma mulher idealista em seu amor à ciência que, convicta do valor da brasilidade e especialmente atenta ao indigenismo, ocupou, na primeira metade do século XX, o protagonismo na escrita da história das ciências sociais na cidade do Rio de Janeiro, então capital da república, na hercúlea missão, até então exclusivamente masculina, de fomentar instituiçóes científicas e culturais para um Brasil que ainda buscava alcançar a modernidade.

Falamos de um tempo em que, sob a forte influência positivista, homens públicos - e algumas poucas mulheres - enfatizavam o desenvolvimento científico como condiçấo sine qua da soberania nacional. Os políticos e os cientistas conversavam, reconhecendo-se mutuamente como artífices de um Brasil que mal se emancipara da metrópole, Portugal. Conforme Gondra e Schueler (2008, p. 28), os museus existentes durante o Império - Museu Nacional do Rio de Janeiro (1818), Museu Paraense Emílio Goeldi (1871), Museu Botânico do Amazonas (1883-1890) - serviram ao projeto político incentivado desde o período regencial (18311840 ) até o Segundo Reinado (1840-1889), de exibição das riquezas locais para fins de sustentar a invenção da nação. 
A aliança entre ciência, preservação da memória coletiva e projeto de nação contida no ideário positivista, mais do que um imaginário, mas uma "estrutura de sentimentos", em acordo com o materialismo cultural de Raymond Williams (2011) ${ }^{3}$, partia da Europa e se "aclimatava” progressivamente nas Américas. Entre o final do século XIX até a década de 1920, assistiu-se à formação e à instauração de museus que se destacavam pelas atividades de ensino e pesquisa científica, em contraposição às instituiçóes do século XVIII, cujas coleçóes haviam sido até então organizadas de acordo com critérios estritamente estéticos: "Os museus conquistam nova lógica e relevância, enquanto espaços onde a nação se faz ao mesmo tempo sujeito e objeto da reflexão" (SCHWARCZ, 1989, p. 23).

Aos museus no Brasil passavam a caber, também, a produção e a divulgação de conhecimentos científicos sobre as riquezas naturais, gentes e culturas desta terra. Em acordo com Domingues (1996), o Brasil representava-se pela opulência das suas riquezas naturais, cuja exploração científica resultou no "colecionismo" de objetos da natureza que faziam a grandeza de tais museus e os inseriam na rede internacional das ciências naturais. Os museus também respondiam pela formação de novos profissionais para o exercício da ciência no Brasil.

O Museu Real, como primeiro se chamou o Museu Nacional, a mais antiga instituição de ciências da América Latina, foi criado pelo decreto de 06 de julho de 1808, funcionando como centro aglutinador de ciência e cultura na Corte. Se, no século XIX, o museu esteve integrado às exploraçôes colonialistas, depois, serviu à afirmação da soberania nacional, de maneira que as pesquisas realizadas pelo seu quadro de cientistas ao mesmo tempo em que desvendavam conhecimentos sobre a natureza permitiram a montagem das ricas coleçóes que retratavam as culturas múltiplas das populaçóes originais no imenso território nacional.

3 Tenho feito uso do conceito de Raymond Williams (2011) com vantagens em minhas pesquisas na sociologia dos intelectuais. Este me ajuda a escapar de uma demasiada ênfase quer na agência humana quer na estrutura. Na verdade, seu "materialismo cultural" supera a cisão entre infra e superestrutura, ressaltando as vivências ou experiências e a chamada "consciência prática", que afetam os sujeitos e são por eles afetadas, necessariamente, relacionais, internas e externas aos individuos, processuais, pouco discerniveis; porém, reais (MIGLIEVICH-RIBEIRO, 20I8). 
$\mathrm{Na}$ atmosfera especial desse tempo ou "estrutura de sentimentos" (Williams, 2011), políticos e cientistas conversavam, e se sobressaía o entusiasmo em torno do país a se construir. No primeiro decênio do século XX, o jovem naturalista e professor do Museu Nacional, Edgard Roquette Pinto (1884-1954), fazia parte do círculo de amizades do já eminente homem público, Alberto Torres ${ }^{4}$, e com ele partilhava a percepção de que faltava ao povo brasileiro a identificaçáo orgulhosa consigo mesmo, capaz de produzir o necessário espirito nacional.

A orientação positivista e o forte sentimento de nacionalidade herdado do pai aproximaram a filha de Alberto Torres de seu futuro mestre, Roquette Pinto, em sua carreira de prestígio no Museu Nacional, que fez de Heloísa seu braço direito. O "capital social" da jovem, que ainda se tornaria a diretora do Museu, traduziu-se em uma sólida posição no campo, inclusive junto ao governo de Getúlio Vargas.

Além de diretora do Museu Nacional, Heloísa Alberto Torres compôs os conselhos dirigentes do Serviço do Patrimônio Histórico e Artístico Nacional (Sphan), do Conselho de Fiscalização de Expediçôes Artísticas e Científicas no Brasil, do Conselho Nacional de Proteção aos Índios (CNPI) e da Fundação Nacional do Índio (Funai). A mulher de ciência pareceu, aos poucos, desprender-se do sobrenome paterno, tornando-se táo somente Dona Heloísa no campo da antropologia no Brasil, que se tornaria, por sua vez, "antes" e "depois" dela, completamente diferente.

Algumas pesquisas têm buscado, há pelo menos dez anos, trazer à luz a personagem de Heloísa Alberto Torres e reconhecer seu notório lugar no seio da "inteligência" brasileira e na história das mais importantes instituiçóes de ciência e de cultura na cena carioca da primeira metade do século XX ${ }^{5}$. Para minha investigação, foram decisivas as entrevistas realizadas

4 O ensaista, bacharel em Direito e político, ideólogo do nacionalismo brasileiro, Alberto de Seixas Martins Torres, natural de Itaborai (RJ), nasceu em 1865, tendo se tornado líder abolicionista eleito para a Constituinte Fluminense, em 1890, e posteriormente para a Câmara Federal, em 1893. Foi Ministro da Justiça aos 30 anos, no Governo de Prudente de Moraes, nos anos de 1896 a 1898, tendo se afastado do cargo para assumir a Presidência do Estado do Rio de Janeiro, de 1897 a 1900. Encerrou a carreira política ao ser nomeado Ministro do Supremo Tribunal, cargo no qual defendeu a extensão do habeas-corpus, ampliando o princípio da liberdade individual. Escreveu duas importantes obras do pensamento social brasileiro: A organização nacional e O problema nacional brasileiro, ambas publicadas em 1914. Alberto Torres veio a falecer aos 51 anos em 1917 (LEMOS, 1995).

5 Cito, a título de exemplo: Corrêa, 1997; Miglievich-Ribeiro, 2000, 2015; Domingues, 2010. 
com as testemunhas de sua trajetória, ao lado, do "mergulho" feito nos acervos do Museu Nacional e na farta documentação deixada por Heloísa Alberto Torres e doada ao Iphan.

Não restam dúvidas de que o Museu Nacional tem na memória de sua excepcional diretora uma inspiraçáo constante para reconstruir, até hoje, a ciência e a cultura brasileiras que literalmente "pegaram fogo" na fatídica noite de 02 de setembro de 2018, na Quinta da Boa Vista, na cidade do Rio de Janeiro. Este artigo postula, pois, somar aos esforços de divulgar o nome desta intelectual cuja vida narra, também, a história de um país em busca de sua identidade e a história de uma disciplina em formação, em um tempo em que era vedada às mulheres a vocaçáo para a ciência. Pretendemos trazer a memória de Heloísa aqui como ponta de lança para que possamos descortinar, também, as não poucas tensóes que fazem da cultura lócus da luta política.

\section{A naturalista e antropóloga}

Nascida em 17 de setembro de 1895, Heloísa Alberto Torres, a filha dileta de Alberto Torres, carregou consigo, ao longo de sua trajetória de vida, não somente o sobrenome mas também o nome de seu pai, o que lhe abriu portas, certamente. Estudou, na infância, no tradicional colégio interno Nossa Senhora de Sion, em Petrópolis, onde fez os estudos referentes ao Primário, ao Ginásio e ao Colegial. Adquiriu diversos conhecimentos humanísticos e científicos, além dos aprendizados linguísticos em latim, francês, inglês e espanhol. Graças à posição social da família, viajou para a Europa e ampliou sua formação cultural. A incontestável vocação para os estudos fez com que, aos 22 anos, após o falecimento do pai, decidisse procurar, no Museu Nacional, o Professor Roquette Pinto, juntamente com a

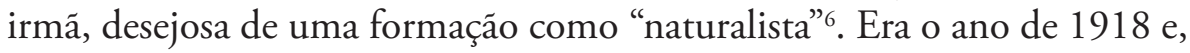
desde então, nunca mais deixou de frequentar o Museu.

6 Em uma entrevista concedida em 1952 e citada por Mariza Corrêa (1997), Dona Heloísa recorda que, saindo do Colégio de Sion, ela. Marieta - sua irmã -, duas filhas de João Baptista Lacerda - ex-diretor do Museu nacional - e uma sobrinha de Pacheco Leão pediram a Roquette Pinto que organizasse um curso para elas versando sobre História Natural. As amigas não prosseguiram na empreitada científica. A irmã tornou-se uma eximia bibliotecária do Museu Nacional. Heloisa teria, por sua vez, uma proeminência muito provavelmente jamais imaginada quando moça ao se dispor a ser estagiária na instituição. 
Roquette transmitiu à discípula as principais liçôes no início de sua carreira. Tendo se iniciado, desde 1906, nos estudos sobre os sambaquis no litoral do Rio Grande do Sul, pois esse tema despertou na jovem cientista especial interesse. As investigaçóes sobre os sambaquis, como eram conhecidos os grandes depósitos conchíferos, davam-se concomitantemente à consolidação do campo da pesquisa e ensino de Antropologia Física, no segundo quartel do século XIX. Às pesquisas impulsionadas desde as primeiras iniciativas científicas de Ladislau Neto, diretor do Museu Nacional nos anos de 1874-1893 que, por sua vez, se inspirava nos trabalhos pioneiros de C.F. Hartt, geólogo norte-americano, somaram-se, depois, o empenho Carlos Wiener que estudou os sambaquis de Santa Catarina bem como de Batista Lacerda, autor de um trabalho famoso sobre o "Homem dos Sambaquis", datado de 1855 (AZEVEDO, 1994, p. 425).

Eram, também, proeminentes no Museu Nacional os estudos sobre os índios, que marcaram, por muito tempo, a predileção dos centros científicos do país. As atividades inauguradas e desenvolvidas no Museu Nacional, desde 1877, por Batista Lacerda foram retomadas por Edgar Roquette Pinto. Entre 1907 e 1908, ele se dedicou aos estudos das coleçôes e dos informes da Missão Rondon, que devassou o noroeste do Mato Grosso. Em 1912, o próprio Roquette se juntou à Comissão Rondon, empreendendo uma expedição à zona entre os rios Juruena e Madeira, região dos índios Pareci e Nhambiquara. Os resultados do trabalho de campo, inicialmente divulgados em conferências realizadas no Museu Nacional, foram publicados em dezembro de 1915, sob o título Série Rondon, que antecipava a renomada obra Rondônia (1938), que lhe deu a consagração no campo.

Roquette Pinto era o professor-chefe da Divisão de Antropologia e Etnografia do Museu Nacional, entre julho e agosto de 1925, quando Heloísa prestou concurso para professora substituta, perante banca examinadora sob a direção de Arthur Neiva. O concurso, de grau de dificuldade afamado, incluiu provas escrita, oral e prática. Nestas, Heloísa disputou com Padberg Drenkpol, Raymundo Lopes, Cornélio Fernandes Netto e Francisco Borja Mandacaru Araújo, obtendo a primeira colocação, por unanimidade de votos, com um total de 38 pontos em um máximo de 40, distinguindo-se em mais de dez pontos do segundo lugar. A imprensa carioca não ignorou o fato, elogiando o ingresso da inteligência feminina 
no serviço à nação, causa com a qual a Antropologia nascida no Museu se identificava nas tarefas de preservação da memória e de construção da brasilidade, conforme demonstra o trecho extraído do Jornal ABC, 12 de setembro de 1925:

Heloísa Alberto Torres, outra expressão fulgurante da mentalidade feminina, conquistou, em concurso notável, a cátedra de Antropologia e Etnografia do Museu Nacional. O êxito do talento e da cultura desta moça veio revelar nela a herdeira legítima das virtudes intelectuais de Alberto Torres. Confessemos que havia certa hesitação em admitir que os poderes públicos homologassem a decisão dos julgadores de uma prova em que foram derrotadas algumas autoridades na matéria [...]. Os louros conquistados pelo feminismo no Brasil são ainda raros. Heloísa Alberto Torres, orgulhosamente solitária, conscientemente distanciada de "coqueteries" e refratária a reclames espetaculares, pode ufanar-se da contribuição que a vitória de sua clara inteligência traz para o advento daquela causa (a nacionalidade) na nossa pátria. (ABC, 1925).

Em 1926, Heloísa iniciou suas expedições, viajando para o litoral de São Paulo a fim de verificar o estado dos sambaquis de Iguape, descritos por Krone. No ano seguinte, partiu para Vespasian, em Minas Gerais, a fim de examinar os sítios arqueológicos. Em 1928, empreendeu uma série de viagens regulares a sítios arqueológicos do rio Iriri, em Magé, ricos em cerâmica pintada de tradição tupi-guarani.

Roquette Pinto, ao deixar o Museu Nacional para se integrar à sua nova seara da Rádio e Educação, já a elegera como sua sucessora. Em 31 de abril de 1930, Heloísa foi nomeada por decreto para o cargo de professor-chefe da Seção de Antropologia e Etnografia do Museu Nacional. Não bastava, porém, a confiança de seu mentor ou seu próprio concurso público para que Heloísa conquistasse o reconhecimento intelectual dos pares, todos eles homens, como antropóloga. Havia um importante rito de passagem para se chegar ao padrão exigido da atividade antropológica ou "naturalista": o trabalho de campo. No mesmo ano, portanto, Heloísa seguiu para sua expedição mais notória, à Ilha de Marajó, um empreendimento raro para uma mulher naqueles anos, o que definitivamente a legitimou no campo ${ }^{7}$.

7 É curioso o fato de que, em 1932, Bastos de Ávila, intelectual, médico, professor de Antropologia do Museu Nacional, autor de No Pacoval de Carimbé, agraciado com o prêmio Ramos Paz da Academia Brasileira de 
A cientista passou, desde então, a ser internacionalmente conhecida em sua expertise: o estudo da cerâmica brasílica, proferindo palestras e publicando suas descobertas e análises, quando deu, então, o salto qualitativo que a emancipava do rótulo exclusivo de "filha de um grande homem de Estado". Apresentava-se, a partir daquele momento, como a disciplinada pesquisadora cuja credibilidade no circuito dos cientistas da época era crescente ${ }^{8}$.

Ao mesmo tempo, Heloísa começava a representar em si o Museu Nacional, instituição guardiã dos maiores acervos em História Natural e Antropologia no Brasil. Os depoimentos dos mais próximos, reunidos em entrevistas realizadas por esta autora, relatam que Dona Heloísa era conhecida também por sua eloquência e porte diante de autoridades e auditórios. Assim, descreveu-a um de meus entrevistados, professor Sólon Leontsines, em entrevista concedida à autora em 16 de março de 1999:

Dona Heloísa era uma pessoa capaz de se entregar a uma causa, de lutar e de botar aqueles que estavam igualmente interessados como irmãos trabalhando juntos. Uma pessoa generosa. Ela se comunicava com todos os diretores dos museus do mundo inteiro através de correspondência, mas tratava todos de igual para igual, de diretor de museu para diretor de museu. Começava a falar [...] um metal de voz. Um contralto. Uma beleza de voz, cheia

Letras, tenha centrado a narrativa de seu romance em torno das aventuras de uma "jovem e brilhante cientista, dona de uma aguda inteligência e tenaz força de vontade", a Srta. Lúcia de Abreu. A personagem protagonizava uma importante e audaciosa expedição à Ilha de Marajó, cheia de percalços, cartas anônimas, fragmentos de mapas, ciladas e charadas que levariam a jovem expedicionária até a arte indigena marajoara, a qual só a partir de 1870 começara a ser citada nos meios científicos nacionais e internacionais. O liuro No Pacoval do Carimbé, entretanto, não narrava uma viagem fictícia nem seus personagens eram frutos da mera imaginação de Bastos de Ávila. As aventuras ali contidas, com liberdade poética, narravam os reais avanços acadêmicos da Antropologia e da Arqueologia advindos da passagem dos estudos de gabinete para a desejada pesquisa de campo de Heloisa Alberto Torres, codinome Lúcia de Abreu. Não me canso de agradecer à generosidade da entrevista a mim concedida, anos atrás, por Padre Fernando de Ávila, na PUC-RJ, filho de Bastos de Ávila, que me presenteou com o romance.

8 Expressa um torrencial de cartas de cumprimentos aquela escrita por Gilberto Freyre, datada de 09 de maio de 1930, quando, na condição de secretário particular do Governador de Pernambuco. Estácio Coimbra. agradeceu à Heloisa a gentileza do envio de seu "interessante trabalho sobre a Cerâmica de Marajó". Na mesma missiva, Freyre coloca-se como "um admirador sincero dos seus trabalhos e do espírito verdadeiramente científico dos seus estudos brasileiros". Em sua célebre obra posteriormente publicada. Casa Grande e Senzala (2013), no capítulo segundo, "O indigena na formação da familia brasileira", Freyre faz referência ao trabalho de Heloísa em nota de fim de capítulo para anunciar o fato de que a divisão do trabalho entre os sexos destinava à mulher índia o manuseio do barro na confecção das cerâmicas, em acordo com a cientista que pesquisou a arte marajoara. 
e de tanta personalidade. Todo mundo dizia: quem ouviu Dona Heloísa uma vez não se esquece mais dela. Porque o que ela dizia tinha substância e depois o que ela falava era com aquela voz linda, com aquela imponência, com aquele saber. Então, a Dona Heloisa foi uma pessoa fantástica. Forte. Bonita. E com aquele olhar de quem é autoridade mesmo e sabe o que quer. (Leontsines, 1999).

Em seus estudos sobre a sobre a cerâmica marajoara, Heloísa observou que as peças marajoaras têm horror ao vazio de maneira que toda sua superfície é completamente coberta com decoraçóes. Fez notar ainda que, embora as mais desenvolvidas artes primitivas americanas sejam acentuadamente naturalistas, a arte de Marajó diferenciava-se pela firmeza rígida da forma geométrica.

Heloísa contrariava os viajantes europeus para quem os povos do vale do Amazonas não pareciam civilizaçôes tão avançadas quanto às da América Central e da Cordilheira dos Andes, com suas suntuosas construçóes de pedra, de forma a não ser àqueles dadas idêntica atenção. Para a cientista, os naturalistas estrangeiros pareciam desconsiderar o fato de que as sociedades primordiais são bem mais coagidas pelos ditames do meio ambiente do que as sociedades complexas. Nesse sentido, se a posse de abundante material de pedra incitou as civilizações centro-americanas à construção de monumentos grandiosos, por sua vez, a população de Marajó, apenas conhecedora da argila, com esta fez sua complexa arte. O desenvolvimento artístico de ambos os povos não pode ser hierarquizado, assim como não seria crível comparar potes com templos, já que não existem templos de barro. Caberia verificar os critérios de abstração artística e, nestes, os ceramistas de Marajó eram uma surpresa feliz para antropólogos e arqueólogos.

A pesquisadora e professora contestava a tese de Louis Agassiz - "difamador de nossa gente", em suas palavras - de que as populaçóes indígenas no Brasil não representavam "mais que restos dispersos e decadentes das civilizaçóes extintas, povos em dispersão". Atribuiu o preconceito para com nossos indígenas aos insuficientes estudos sobre os artistas oleiros. Mas, citando as expediçôes realizadas por Hartt e outros, mostrou que, enfim, a arte de nossos índios estava sendo resgatada em seu valor (TORRES, 1929, p. 3). Superou teorias tais como de Posnanski por pretender explicar os desenhos marajoaras em analogia aos fenômenos naturais, invalidando a comparação feita pelo naturalista entre um escalonado e um raio, como 
se os artistas de Marajó assim representassem um raio. Heloísa expunha que as peças de cerâmica da civilização de Marajó revelavam formas bojudas e elípticas, triangulares, abauladas, sempre ricamente ornamentadas, o que lhes conferia raro cuidado artístico. Para a antropóloga, a sofisticação artística dos marajoaras somente foi possível graças ao retardamento na aquisição de um bem cultural objetivo - o conhecimento da cerâmica que deu tempo para que, na arte do trançado, as geraçóes se dedicassem ao aperfeiçoamento dos desenhos na superfície. Confirmando a tese de Max Schmidt - eminente mestre do Museu de Etnografia de Berlim que trocara a universidade pelas pesquisas entre os índios brasileiros -, a cientista reafirmou:

A arte, na opinião tão bem fundamentada de Max Schmidt, surgiu da técnica. Uma vez constituído o primeiro motivo ornamental, terá então impressionado a sensibilidade do artífice que, desenvolvendo-o, transformava-se em artista consciente, introduzindo alterações na própria técnica, na disposição dos padrões, na criação de figuras de animais etc. Mas o móvel primeiro foi uma circunstância decorrente da técnica. (TORRES, 1929, p. 22).

É, também, instigante que Heloísa tenha registrado o fato de que, na região das Américas, apenas as mulheres eram oleiras. Assim, em que pese caber exclusivamente aos sacerdotes homens o desenho dos motivos decorativos, não deixava de considerar a relevância da atividade feminina:

[...] Se a arte sofre o constrangimento da matéria-prima, a mesma foi condicionada por mãos femininas [...], a mulher, quando lhe coube passar a seu campo de atividade a arte desenvolvida que o homem criara, mostrou-se à altura do companheiro e, mais previdente do que ele, soube imprimir em matéria durável a perpetuação de uma cultura forte. (TORRES, 1929, p. 29).

A ousadia e a firmeza de suas críticas em um mundo masculino atraíam os olhares de muitos. Conforme salientou Mariza Corrêa (1997), Heloísa foi a primeira a observar que sua condição feminina parecia passar despercebida quando em seus êxitos, mas nos revezes, quando algo vinha depor contra sua competência profissional, pesava sobre ela a acusação de ser mulher, o que significa afirmar que, enquanto vitoriosa, a questão de gênero era neutralizada, bastando, contudo, qualquer polêmica para que viessem à tona fartamente as conhecidas depreciaçóes a uma mulher de pulso, tais como as acusaçôes de "autoritária" e "arrogante". 


\section{A diretora do Museu Nacional}

Aos poucos, as atividades administrativas de Heloísa tornavam-se cada vez mais intensas. De 1935 a 1937, exerceu a função de vice-diretora do Museu Nacional, eleita pela Congregação, sendo o diretor Alberto Betim Paes Leme. Foi reeleita por dois períodos consecutivamente imediatos, 1936 e $1937^{9}$, mantendo a unanimidade dos votos da Congregação. Em fins de 1938, assumiu o cargo de diretora do Museu Nacional, por Decreto-Lei do Presidente da República, Getúlio Vargas, no Estado Novo, permanecendo como tal até 1955 , substituída, depois, por José Candido de Mello Carvalho, a quem se seguiu, em 1961, Newton Dias dos Santos ${ }^{10}$.

Sua gestão foi vinculada aos distintos períodos varguistas: o autoritário (1937-1945) e, posteriormente, o período democrático. Durante todo o tempo, as relaçôes de Heloísa Alberto Torres com os primeiros escalóes do Governo Federal foram bastante próximas. A fama de Alberto Torres, como já assinalado antes, a precedia. De acordo com Sólon Leontsines (1999), meu entrevistado:

Getúlio Vargas tinha uma distinção muito grande para com ela. Pequenininha já frequentava os gabinetes de pessoas importantes. [...] Tinha um trânsito muito grande com o pessoal antigo até o governo do Getúlio, e logo depois, do Dutra. Ela tinha um trânsito total. Ligava para o Palácio do Catete com a maior naturalidade. Ligava para o Ministério da Educação. [...] Conseguiu manter esse prestígio, de certa maneira, até o final da vida.

Em que pesem as relaçóes de Heloísa Alberto Torres com o governo serem de proximidade e mútua simpatia, as medidas políticas do Estado Novo nem sempre lhe foram favoráveis. A lei de desacumulação de cargos, como ficou conhecido o art. 159 da Constituição de 1937, regulamentado pelo Decreto-Lei no 284, de 29 de novembro do mesmo ano, atingiu "em cheio" os cargos do magistério e técnicos científicos ao proibir a acumulação de cargos públicos remunerados quando da União, dos Estados e dos Municípios. A consequência foi o êxodo abrupto de valiosos quadros da

91937 é, também, o ano em que Roquette Pinto deixou o Museu Nacional para se dedicar à nova seara da Rádio e da Educação.

10 O Museu Nacional apenas teria novamente uma mulher em sua direção no ano de 1994, quando Janira Martins Costa foi eleita para o cargo. 
instituição, tais como Cândido de Mello Leitão, Francisco Venâncio Filho, Padberg Drenkpol, Hamilton Nogueira, Paulo Parreiras Horta, René Laclette, Rui Maurício de Lima e Silva, Alberto Childe, coincidindo com o primeiro ano da gestão de Heloísa.

Seu primeiro desafio como diretora estava colocado: repovoar o $\mathrm{Mu}$ seu Nacional. A imposição legal de ingresso na carreira somente pela classe inicial impedia, entretanto, a atração de cientistas experientes. Além disso, os inúmeros dispositivos legais para a contagem de tempo de serviço embaraçavam possíveis transferências para o serviço federal, por exemplo, de funcionários estaduais interessados nas atividades do Museu Nacional. Restou, assim, à Heloísa um único recurso: a convocação dos jovens estagiários, que se iniciavam ainda nos domínios da Antropologia, Botânica, Geologia e Zoologia, para ocupar interinamente as vagas deixadas pela evasão dos pesquisadores. Não de outro modo, a diretora conseguiu manter o Museu em funcionamento se não assegurando a permanência daquele quadro profissional até 1944, quando, conseguiu, em virtude de seu infatigável empenho pessoal, a abertura de vagas para concurso junto ao Departamento de Administração do Serviço Público (Dasp). Naquele ano, foram abertos os concursos públicos de provas e títulos para as quatro grandes divisóes do Museu Nacional: Zoologia, Geologia e Paleontologia, Botânica e Antropologia. Ingressaram na instituição doze jovens pesquisadores, dentre eles, Luiz de Castro Faria, Eduardo Galvão e Luiz Emygdio de Mello Filho, conforme consta no Memorial de HAT, 21 de dezembro de 1945.

Heloísa, personalidade-chave no "repovoamento" do Museu Nacional e na sobrevivência de suas atividades, seguiu a trilha do antigo e prestigiado diretor, Ladislau Netto, também, no impulso aos intercâmbios com institutos nacionais e internacionais. Em acordo com Domingues (2010), o Museu estabeleceu vínculos de pesquisa com a Fundação Rockefeller e a Smithsonian Institution, além de convênios com universidades como a Stanford e a Columbia, nos EUA, desde os anos 1930. No imediato pós-guerra, Heloísa Alberto Torres colocou ainda o Museu em contato com os organismos internacionais então criados, como a Organização das Naçôes Unidas (ONU) e a Organização das Naçóes Unidas para a Educação, Ciência e Cultura (Unesco). A diretora do Museu representou, também, 
o Brasil no Conselho Internacional de Museus (Icom) - órgão da Unesco que trata dos museus. Em 1946, Heloísa integrou-se, bem como o Museu, ao projeto de criação do Instituto Internacional da Hileia Amazônica, da Unesco, do qual chegou a ser diretora interina. Tratava-se, então, como descreve Heloísa Domingues (2010), de um ambicioso plano de governo que unia a visão de desenvolvimento à preocupação ecológica e cultural, nascido nas salas do Museu Nacional e que deviam à pessoa de Heloísa e à sua inteligência e capacidade para tecer redes transnacionais a chance de funcionamento, ainda quando em circunstâncias institucionais desfavoráveis:

O projeto do Instituto, de autoria do bioquímico Paulo Carneiro, acabou por se tornar prioritário na UNESCO, pois reuniria cientistas dos países amazônicos e seria uma primeira instituição que trabalharia as ciências naturais e antropológicas sem se restringir às fronteiras políticas dos países. Ou seja, abrigaria cientistas de vários países que integram a região amazônica. O trabalho de instalação e a organização da primeira reunião do Instituto realizaram-se nas dependências do Museu, que se tornou por muitos anos uma espécie de sede do Instituto, para onde era dirigida a sua correspondência (Petitjean e Domingues, 2000; Domingues e Petitjean, 200 I ). Essa consolidação dos laços internacionais do Museu Nacional, tal como se deu naqueles anos, não era apenas reflexo de um status cumulativo conseguido ao longo da história institucional, mas se devia também à identidade de ideias de Heloísa Alberto Torres com o internacionalismo científico e com a visão do papel social das ciências preconizada por aqueles grupos que estavam à frente da UNESCO - Julian Huxley, primeiro diretor geral, e Joseph Needham, primeiro chefe da Divisão de Ciências Naturais, que abrigava também a antropologia - e com Paulo Carneiro, o embaixador do Brasil naquele órgão internacional. (DOMINGUES, 2010, p. 631).

Fato é que o Museu Nacional manteve, na gestão de Heloísa Alberto Torres, uma assídua colaboração com o Museu Paraense Emílio Goeldi, a Faculdade de Filosofia e Letras da Universidade de São Paulo, o Serviço de Proteção aos Índios, o Departamento de Zoologia do Estado de São Paulo, a Divisão de Caça e Pesca do Ministério da Agricultura, a Comissão de Piscicultura do Nordeste, o Ministério da Viação, o Serviço de Produção de Peixes e Animais Silvestres do Estado de São Paulo, o Jardim Botânico do Rio de Janeiro e o Serviço Geológico do Ministério da Agricultura. Além, da especial notoriedade advinda dos intercâmbios com os institutos de pesquisa norte-americanos, alguns já citados, Rockfeller Foundation, Carnegie Foundation, Comittee for Artistic and Intellectual Relations with 
Latin America, Columbia University, Northwestern University, University of Michigan, The United States National Museum, Chicago Museum, Buffalo Museum of Science, Stanford University, conforme Memorial de HAT (1945). Há de se reconhecer, também, seu impulso às publicaçôes científicas nacionais e internacionais mediante a prática da permuta em uma época em que o mercado editorial praticamente inexistia no país.

O Museu Nacional tornava-se definitivamente órgão de atração de pesquisadores para o Brasil. Em 1939, a Universidade de Columbia e o Museu Nacional, que vinham dialogando desde a gestấo de Roquette Pinto, estabeleceram um acordo que garantia a vinda de pesquisadores estrangeiros e, também, a formaçấo dos etnólogos brasileiros no exterior. Beneficiou-se desse convênio, dentre outros, Charles Wagley:

A Universidade de Columbia tinha um acordo informal com o Museu Nacional do Rio de Janeiro para co-financiar [sic] estudos etnológicos no Brasil. Eu já mencionei Willian Lipkind, cuja pesquisa foi financiada pelo Museu, mas dois outros colegas, Ruth Landes e Buell Quain, também estavam trabalhando no Brasil sob os auspícios do Museu. (WAGLEY, ano apud MASSI, 1989, p. 442).

Ralph Linton, Alfred Métraux, Paul Rivet, Claude Lévi-Strauss, desde 1935, mantinham correspondências regulares com Heloísa Alberto Torres. Charles Wagley chegou ao Brasil em janeiro de 1939, instruído por Métraux sobre os caminhos da pesquisa na América do Sul, que incluíam, no Rio de Janeiro, o contato com Heloísa Alberto Torres. Através de Buell Quain, Wagley foi apresentado à Heloísa. Em 09 de fevereiro daquele ano, atraído pelo estudo dos índios Tapirapé, Charles Wagley contou com o apoio decisivo da diretora para a autorizaçáo, pelo governo, de sua expedição. Como contrapartida, Heloísa incluiu dois de seus alunos na viagem, Eduardo Galvão e Nelson Teixeira ${ }^{11}$.

11 Segundo depoimento de Charles Wagley, o trabalho de campo entre os Tapirapé tornou-se possivel por subvenção do Columbia University Social Science Research Council e foi feito sob a direção do Dr. Ralph Linton, do Departamento de Antropologia, Universidade de Columbia. No Brasil, as expedições aos Tapirapé foram feitas sob os auspícios do Museu Nacional. Durante o mês de abril de 1940, entre os Tapirapé, reuniram-se a Wagley dois estudantes do Museu Nacional: Eduardo Galvão e Nelson Teixeira. O mês foi dispendido em treinamento de técnicas de campo para coleta de material etnográfico. Assim, iniciou-se um projeto de treinamento em etnografia, continuado em 194I e 1942, com subvenção do "Comitee for InterAmerican Intellectual and Artistic Relations". Wagley voltou ao Brasil para trabalhar no Museu Nacional em julho de 194I. Organizou-se, assim, 
O intercâmbio com pesquisadores estrangeiros tornou-se uma atividade regular e rotineira. Charles Wagley, William Lipkind, Ruth Landes e Buell Quain foram recebidos no Museu Nacional. Heloísa assegurou ainda a vinda de James e Virgínia Watson, Yolanda e Robert Murphy. Willian Lipking passou 14 meses entre os Carajá e, sobre eles, escreveu um capítulo do Handbook of South American Indians; Ruth Landes, interessada no estudo das relaçóes raciais entre brancos e negros, fez pesquisas na Bahia, cujos resultados foram publicados em Cidade das Mulheres; Buell Quain pesquisou os Trumaí e publicou, em 1955, com Robert Murphy, The Trumai indians of Central Brazil. Jules Henry trabalhou junto aos Kaigang, cujos resultados publicou em Jungle people. Wagley foi quem estabeleceu o contato mais prolongado com o Museu. Após passar 15 meses entre os Tapirapé, entre 1939 e 1940, visitou-os frequentemente nos anos de 1940 e 1950, passando seis semanas em campo, e, mais tarde, em 1965 (MASSI, 1989, p. 442).

A participação dos jovens pesquisadores do Museu Nacional em expediçóes conduzidas pelos estrangeiros fazia parte do plano traçado por Heloísa para a formação e o treinamento em pesquisa de campo dos futuros antropólogos brasileiros. Luiz de Castro Faria, Eduardo Galvão, Nelson Teixeira, Rubens Meanda, Pedro Lima, depois, Tarcísio Torres Messias e Marília Alvim são exemplos de especialistas cuja formação deveu-se ao apoio fundamental de Heloísa.

Por ser membro influente do Conselho de Fiscalização das Expediçóes Artísticas e Científicas no Brasil, a diretora do Museu pôde criar e executar um programa institucional, largamente documentado, que visava, dentre outros aspectos, ao treinamento de antropólogos, com especial valorização da etnologia. Investiu, por exemplo, na formação de Castro Faria, ao conseguir vinculá-lo a uma das expediçóes de Lévi-Strauss no Brasil, em 1938. Em relação a Eduardo Galvão, foi ela também a responsável por conduzi-lo, no momento inicial de sua carreira, ao Instituto LaFayette, onde ele se formou no curso de Geografia e História para, então, depois, retornar 
ao Museu Nacional. Heloísa, na verdade, foi responsável pelo encaminhamento de não poucas carreiras também nas demais Divisóes do Museu Nacional. Em Memorial de HAT (1945), os registros apontaram que o número de técnicos subira de 24, em 1938, para 61.

Castro Faria entrou no Museu em 1936, nomeado, quando do repovoamento, naturalista interino, na vaga de Padberg Drenkpol, em 1937, prestando, conforme já assinalado, posterior concurso para a Divisão de Antropologia. Durante a gestão de Dona Heloísa, realizou inúmeros trabalhos etnográficos, desde os estudos de comunidade de pescadores de Gargaú, na Paraíba - um dos pontos de contato entre a zona litorânea e o chamado sertão -, o estudo das feiras nordestinas, até as pesquisas paleotnográficos e paleoantropológicos nas jazidas de sambaquis em diversas localidades do Rio de Janeiro, São Paulo, Paraná, Santa Catarina e Espírito Santo, relativas aos sambaquis referentes ao século XIX e parte do século XX, acompanhados de seus próprios trabalhos de campo. Não é fortuitamente que Castro Faria, em entrevista concedida em 18 de março de 1999, reconhece:

A Heloisa iniciou-me em Arqueologia e em Etnologia. Trabalhei sempre com ela. Eu fiz concurso para o Museu Nacional e na banca estavam Roquette Pinto, Raymundo Lopes e Heloísa. Logo depois, teve o convívio lá dentro e a gente vai se aperfeiçoando cada vez mais. Depois eu fui para a França, eu tive bolsa, e lá estudei. Ela levou, inclusive, vários estagiários a fazer o curso.

Eduardo Galvão, por sua vez, ingressou no Museu Nacional, em agosto de 1942, como naturalista-auxiliar interino e foi efetivado nesse cargo em março de 1945, após concurso de provas, no qual obteve a primeira colocação. Em novembro de 1945, como tantos, foi nomeado, interinamente, naturalista. Integrado à equipe de antropologia do Museu Nacional, com apoio de Heloísa e Charles Wagley, Galvão obteve, em 1947, uma bolsa do Institute of International Education, com a assistência do governo dos Estados Unidos da América do Norte e complementaçóes da Viking Fund, do Departamento de Antropologia da Columbia University e da Society for Advancement of Sciences de Washington, para realizar estudos pós-graduados ${ }^{12}$. No retorno, reintegrado ao corpo do Museu Nacional, em

12 Galvão deixou o país rumo aos Estados Unidos sem a obtenção anterior da concessão de licença pelo governo brasileiro. Em entrevista concedida à autora, Castro Faria menciona que "aborrecido com a burocracia 
1947, passou a colaborar com a Fundação Brasil Central, na área do Xingu e, em 1951, o antropólogo deu início a um segundo projeto, também por sugestão de Heloísa Alberto Torres, na área do Rio Negro. Quando do término desse projeto, desligou-se definitivamente do quadro funcional do Museu Nacional para, em 1952, se tornar Chefe da Seção de Orientação e Assistência do Serviço de Proteção aos Índios (SPI) e, também, chefe da Divisão de Antropologia do Museu Paraense Emílio Goeldi, de 1955 a 1962 e, depois, de 1965 até 1976, ano em que faleceu. No SPI, Galvão trabalhou com Darcy Ribeiro, de quem recebeu o convite para ser chefe do Departamento de Antropologia na Universidade de Brasília (UnB) nos anos de 1963 e 1964 . Tais fatos nos ajudam a pensar a expansão das redes intelectuais de Heloísa, à frente das articulaçôes de fomento a diversas expediçóes e estudos etnográficos totalmente custeados pelo Museu Nacional que conciliavam a formação dos jovens pesquisadores ao enriquecimento das coleçóes do Museu Nacional em todas as Divisóes.

Em Miglievich-Ribeiro (2000, 2015), destaquei que, dentre alguns exemplos relacionados à Divisão de Antropologia, no primeiro ano de Heloísa como diretora, foram adquiridos 18 espécimes arqueológicos da coleção de Atílio Pittiagliani, que realizou estudos na Ilha de Santana. Também foi incorporada ao Museu a coleção de material etnológico organizada por Curt Nimuendajú ${ }^{13}$. Em 1939, a Divisão de Antropologia recebeu, entre outras, a coleção de artefatos dos Índios Bororo, oferta do Departamento de Aeronáutica, com o qual Heloísa Alberto Torres mantinha intercâmbio. Em 1940, através do Conselho de Fiscalização, era trazido para o Museu

intransigente que, sem considerar sua história de dedicação ao Museu Nacional, obrigava-o a optar entre a pós-graduação na Universidade de Columbia ou sua permanência no Museu", Eduardo Galvão optou por Columbia a despeito das consequências. Em seu regresso, porém, ao Brasil, após ter concluído os créditos do doutorado, Heloísa providenciou sua readmissão intervindo diretamente contra a acusação de abandono de cargo, conseguindo provar que Galvão havia pedido exoneração.

13 Etnólogo de renome internacional (1883-1945), por mais de 40 anos (1903-1945), viveu nos sertões entre tribos indigenas, tendos se tornado um "dos melhores conhecedores dos índios do Brasil". Amigo e defensor dos aborigenes, colaborador infatigável do Serviço de Proteção aos índios, deixou numerosas publicações, entre as quais sobressaem os notáveis trabalhos sobre "a lenda da criação e da destruição do mundo como fundamento na religião dos apapocuva-guarani". Brasileiro de origem alemã, cujo nome de familia, Unkel, foi trocado por Nimuendajú (guarani), teve seu primeiro contato com o Conselho de Fiscalização supervisionado por Heloísa Alberto Torres e, em suas expedições no Brasil, encontrava nesta o empenho irremovivel em promovê-las. Enriqueceu consideravelmente as coleções do Museu Nacional (AZEVEDO, 1994; CASTRO FARIA, 1998). 
o material etnográfico de Hans Krieg. Também nesse ano, Castro Faria visitava os sambaquis de Santa Catarina e trazia diversas peças para o $\mathrm{Mu}$ seu Nacional. Em 1941, realizou estudos etnográficos no Mato Grosso e em Campos, no Rio de Janeiro, incorporando às coleçóes do Museu 1.639 peças. Em 1943, Eduardo Galvão estudou os Guarajaras, enquanto Nelson Teixeira, James Watson e Virgínia Watson pesquisaram duas aldeias Caiuá, entre Ponta Porã e Nhuverá. Trazem 268 exemplares para as coleçóes do Museu. O movimento permaneceu ao longo da década de 1940. Em 1945, Eduardo Galvão, Nelson Teixeira e Pedro Lima estudaram o grupo indígena Tenetehara. Os dois primeiros elaboraram um catálogo da cultura material desses aborígenes. A Divisão de Antropologia recebeu deles 775 novos exemplares para suas coleçôes. Registra-se que, em 1949, os irmãos Villas Bôas ofereceram ao Museu Nacional duas peças dos índios do Xingu; Atílio Tippigliani doou duas peças arqueológicas encontradas em Santa Catarina; José Maria Valente ofereceu uma peça dos índios Macuchi. Ainda nesse ano, foram adquiridas 44 peças etnográficas da coleção organizada por Marcos Jímenez sobre os índios do Vale do Rio Negro. Na década de 1950, a aquisição de peças para o Museu diminui. Heloísa voltou-se para a sua organização. Em 1954, antes de deixar a Direção, concluiu a reorganização definitiva das coleçôes de arqueologia indígena e iniciou o tratamento especial das peças de plumária. Foi revista a classificação das flechas, devidamente organizadas em armários especiais. Incluíram-se 234 novas peças na coleção de Etnografia entre os objetos trazidos das expedições às sociedades indígenas.

O maior desafio que a diretora impôs a si mesma, no entanto, foi a inadiável reforma total do prédio do Museu Nacional. Os tempos hostis que fizeram atrasar em demasiado a finalização da obra, seu desgaste político pessoal, em consonância à mudança também na vida pública brasileira, geraram conflitos que não lhe fizeram justiça em sua própria Casa, o que, também, se explicava pelas diferentes reestruturaçôes administrativas sofridas pela instituição durante sua gestão ${ }^{14}$.

14 Entre 1930 e 194I, o Museu Nacional deixou de estar submetido ao Ministério de Agricultura, Indústria e Comércio para compor a Universidade do Rio de Janeiro, no âmbito do Ministério de Educação e Saúde, o que provocou uma redução gradativa da autonomia científica institucional. No período de maior prestígio da diretora junto a Getúlio Vargas, contudo, o Museu voltou a se desligar da universidade e a usufruir de sua 
Ainda assim, Domingues (2010) salienta que, em 1946, nas circunstâncias de enfraquecimento institucional, Heloísa Alberto Torres na direção do Museu, seu reconhecimento internacional e papel político nos debates nacionais não se esmaeceram, antes, se reforçaram, ou não teria se mantido a cientista no front das principais iniciativas em torno do desenvolvimento das ciências naturais e antropológicas no país ${ }^{15}$.

\section{A reformadora do Museu Nacional}

Entre 1939 e 1940, foi efetivado um acordo entre o Serviço do Patrimônio Histórico e Artístico Nacional (SPHAN), assinado pelo seu diretor, Rodrigo Melo Franco de Andrade, e pela diretora do Museu Nacional, que também era conselheira daquele órgão. O SPHAN obtinha as verbas necessárias para a realizaçáo das obras no prédio do Museu, cuja necessidade foi verificada mediante exames técnicos contendo documentação fotográfica e descritiva detalhada, registrada nos Livros de Tombo referentes aos anos em questão. A precariedade da segurança devido ao péssimo estado de conservação do prédio, que costumava receber, aos domingos, de 3.000 a 4.000 visitantes, tornou inevitável a interrupção das visitas públicas enquanto as obras não fossem realizadas. Fazê-las era um dever da diretora, que contrariou de início alguns interesses e implicou desafetos, mas também a admiração de outros, conforme se verifica em trecho da Carta de Paschoal Leme para "O Globo", 13 de março de 1977: "Só mesmo a

condição singular no plano federal (Decreto-Lei n 29.974, de 23 de janeiro de 194I). O decreto foi revogado assim que mudou o governo getulista, sendo incorporado, em 1946, à recém-criada Universidade do Brasil, com prerrogativas de Escola e Faculdade, integrado ao Fórum de Ciência e Cultura (CARVALHO, 1977, p. 33), um status bastante decrescido que encontrou em sua diretora uma ferrenha crítica que declarava o caráter inusitado, em qualquer lugar do mundo, de um museu de caráter nacional se encaixar como uma unidade de uma estrutura universitária, que não poderia, faticamente, geri-lo em suas demandas específicas. Seus protestos, contudo, não foram ouvidos pelas autoridades competentes.

15 Domingues (2010) refere-se mais precisamente ao protagonismo da persoangem no projeto da Hiléia Amazônica também descrito por Maio e Sá (2000). Logo após o fim da Segunda Guerra, a Unesco constituiu-se em lócus privilegiado da discussão acerca da destinação social da ciência em regiões periféricas tendo em vista os efeitos do conflito mundial tais como a fome, os refugiados, os desequilibrios ambientais e as desigualdades socioeconômicas. 0 interesse pela pesquisa da riqueza biológica e ecológica dos biomas de florestas úmidas tropicais foi um dos pontos da agenda científica e política da Unesco, que se traduziu em projetos como o da criação de um "laboratório científico internacional na Amazônia" que, sob os auspícios da Divisão de Ciências Naturais, fundou o Instituto Internacional da Hileia Amazônica (IIHA), um dos quatro principais projetos da Unesco para o ano de 1947, cujo protagonismo, ao lado de Paulo Carneiro, era de Heloísa Alberto Torres. 
coragem dessa mulher extraordinária poderia enfrentar situação dessa natureza. Assumiu a responsabilidade de fechar o Museu à visitação pública e com energia invulgar lançou-se à sua reorganização".

Em reuniáo com os técnicos do SPHAN, os respectivos diretores - do SPHAN e do Museu Nacional -, bem como os chefes de seção, reconheceram a inviabilidade da transferência para outro edifício ou a construção de novo prédio. A solução imediata pareceu ser a restauração da sede e a permanência nesta após sua conveniente restauraçáo. Os pareceres técnicos concluíram, também, pela inviabilidade de obras setoriais. As obras de grande vulto exigiam: 1) a consolidação do prédio que ameaçava ruir; 2) a instalação de uma rede de abastecimento d'água e de grandes depósitos, pois, naquelas circunstâncias, após as $15 \mathrm{~h} 30 \mathrm{~min}$, alguns laboratórios deixavam de receber água da rua; 3) a instalação de nova e mais ampla rede de gás, dada a obstrução quase completa do antigo sistema; 4) a instalação de rede embutida de iluminação elétrica, visto que os moldes anteriores já se encontravam condenados; 5) a substituição de pisos e respectivas barras de sustentação; 6) a criação de novo acesso ao Museu e o desdobramento da portaria - para funcionários e visitantes -; 7) a redistribuição do espaço, tendo em vista a ampliação dos laboratórios; 8) a distribuição das salas de exposição em vista dos grandes espécimes a serem expostos megatério, baleia, elefantes, girafa; 9) as novas instalações levando-se em conta as restriçóes às obras, dado o caráter tradicional do prédio, que não poderia ser alterado.

A redistribuiçãa do espaço foi planejada consultando-se os melhores museus estrangeiros, sobretudo para a orientação sobre as coleçôes zoológicas. O primeiro pavimento - térreo -, cuja altura exígua do pé direito impedia um uso mais amplo, foi destinado à Divisão de Geologia e Mineralogia, à Divisão de Antropologia e ao Departamento de Extensão Cultural. O segundo pavimento, retirada a Biblioteca, passava a abrigar as Divisóes de Botânica, Zoologia, parte da Antropologia, Geologia e Paleontologia e, também, o megatério. No terceiro pavimento, ficariam localizadas, então, a Administração e a Biblioteca, além da seção de Publicações do Departamento de Extensão Cultural. Nas palavras de Lygia Martins Costa, minha entrevistada em 09 de março de 1998, que trabalhou com Heloísa no SPHAN: 
Dona Heloisa fez uma reformulação total no Museu. Criou aquelas seções para dar uma organização temática. Mas não queria só uma organização temática. Queria que fosse bem apresentada. E pediu ao Dr. Rodrigo, diretor do SPHAN, que arranjasse um "displayer", arquiteto que "bola" toda a apresentação de um Museu. Então, o Dr. Rodrigo recomendou o mesmo que estava trabalhando com ele. Um arquiteto francês que estava trabalhando no Museu da Inconfidência. [...] Ele foi para lá e fez uma organização exemplar. Mas foi só a parte da Arte Antiga [...] da África, da arqueologia, parte do Egito, aquela parte toda antiga. Todo mundo comentava a organização e a qualidade da apresentação. E ela acompanhava. Dava opinião. [...] Acompanhou essa parte museológica de perto, porque ele era um arquiteto, não um museólogo. O museólogo é o cientista do campo de conhecimento. É aquele que diz o que deve ser apresentado. Faz a seleção. Diz em que sequência deve ser apresentada, que agrupamentos devem ser feitos e que peças devem ser destacadas. Isso cabe ao museólogo, que é o conhecedor científico do material que está sendo exposto. Ela era a museóloga.

Para o início das obras, as exposiçóes foram desmontadas em primeiro de outubro de 1941. Estimou-se que o projeto completo levaria três anos para ser executado, prevendose uma revisão orçamentária anual. As expectativas, porém, foram frustradas com a mudança do cenário global com a Segunda Grande Guerra, que inviabilizou, dentre outras, a aquisição do material da obra. As difíceis condiçóes gerais da administração pública e as inconveniências impostas pelos trabalhos imensos de reorganização do Museu conviveram, assim, com a desmontagem das exposiçóes e a simultaneidade das obras nos vários laboratórios, praticamente paralisadas daquela data até $1946^{16}$, o que significou o fechamento do Museu Nacional à visitação pública - uma de suas funçóes, como dissemos, mais reconhecidas, sobretudo junto às escolas da rede pública - até seu recomeço após o fim da Segunda Guerra, em ritmo lento e concluídas na sua totalidade apenas em 1954.

Ao término do Estado Novo, em 1945, com as obras ainda praticamente paralisadas e as exposiçóes desmontadas, explodiu uma das

16 Em meio aos obstáculos, já em 1941. Heloisa pôde se dedicar à reorganização dos serviços da Biblioteca, procurando adaptá-la aos novos sistemas em voga nas instituições de maior prestígio no mundo. Formou uma equipe de II funcionários especializados, portadores de títulos de bibliotecários, e enumerou, com Helena Maria da Costa Azevedo, bibliotecáriachefe, as providências necessárias para que a biblioteca alcançasse o nivel de excelência. Transferida para o terceiro pavimento do Museu, a biblioteca teve suas instalações ampliadas para cinco salas, às quais foram acrescentadas, posteriormente, outras duas salas. A diretora providenciou também um tratamento adequado à preservação do acervo, recatalogado com 67.849 volumes. A biblioteca foi equipada com estantes, mapotecas, novos fichários, máquinas de escrever, graças a doações do Serviço do Patrimônio Histórico e Artístico, segundo consta no Memorial de HAT (1945). 
maiores crises no Museu Nacional. Heloísa começou a receber críticas, em tom pessoal e ofensivo, incluindo telefonemas e telegramas anônimos, advindas de seus adversários no Museu: Haroldo Pereira Travassos, Othon Leonardos, Emannoel de Azevedo Martins, Carlos de Paula Couto, Newton Dias dos Santos, Valter da Silva Curvelo, Dalci de Oliveira Albuquerque, Romualdo Ferreira de Almeida, Baldomiro Barcia Gonzales, Joaquim Pereira Machado Filho, Alceu Lemos de Castro, Candido Simóes Ferreira, José Oiticica Filho.

No Museu, contudo, um significativo grupo prestava solidariedade à Heloísa Alberto Torres e via nos ataques à sua pessoa uma luta para bani-la da longeva direção. De seu lado, estavam os chefes de Divisão Viktor Leinz, de Geologia e Mineralogia; Luiz Emygdio de Mello Filho, de Botânica; os naturalistas Bertha Lutz, Antenor Leitão de Carvalho, José Lacerda de Araújo Feio, Eduardo May, Luiz de Castro Faria, Eduardo Galvão, Tarcísio Messias, Pedro de Lima; o naturalista-auxiliar Mário Rosa; o zoólogo José Candido de Melo Carvalho; o técnico-chefe da Seção de Extensão Cultural Pascoal Leme; o técnico de Educação Vítor Stawiark; o oficial administrativo Roberto Silveira; a encarregada da Biblioteca Helena Maria da Costa. O grupo foi fortalecido com o apoio dos antigos professores Roquette Pinto, Cândido de Melo Leitão e Rui Maurício de Lima e Silva, bem como de Alberto Childe - ex-conservador de Arqueologia Clássica. Também os funcionários mais humildes prestaram solidariedade à diretora que recebeu, em 17 de dezembro de 1945, um abaixo-assinado contendo 51 assinaturas (MIGLIEVICH-RIBEIRO, 2000; 2015).

Os ânimos exaltados acompanharam todo o ano de 1945 que marcou o término da Segunda Guerra Mundial, o fim do Estado Novo no Brasil e a aclamação de eleiçóes gerais. Em 1946, Eduardo Galvão escreveu a Charles Wagley:

Não temos feito outra coisa no Museu que trabalhar na exposição, e como estamos longe do fim, a situação permanece a mesma. Inquéritos, processos, representações e o diabo para cima de Dona Heloísa. Não é para menos, os pequeninos estão dando tudo para tomarem conta do negócio, aproveitar-se de tudo que foi feito até agora, para então reabrir o Museu e fazer a "caveira" de nossa querida amiga. Nós não podemos senão ativar ao máximo o trabalho, pois se conseguirmos abrir ao público a exposição de antropologia, a batalha está ganha para o nosso lado. (GALVÃO, 1946, apud CORRÊA, 1997, p. 43). 
Em 21 de novembro do mesmo ano, Heloísa, contrariada, recebeu do Ministro da Educação Souza Campos a ordem para proceder às eleições para diretor do Museu. A essa altura dos acontecimentos, as críticas haviam extrapolado os limites do Museu Nacional e a imprensa propagava o conflito. Às vésperas das eleiçôes, Newton Dias dos Santos concedeu uma entrevista ao vespertino $A$ Noite, acusando a diretora de desleixo com a Reforma do Museu, perda de peças do megatério e descuido com os sarcófagos. No dia da eleiçáo, a matéria foi afixada provocativamente nas paredes do Museu. As eleiçóes tumultuadas, e antecipadamente colocada sob suspeita, prosseguiram, saindo vencedor Othon Leonardos ${ }^{17}$, com 21 votos, dez a mais do que Heloísa Alberto Torres. Os demais candidatos, Antenor Leitão de Carvalho, José de Araújo Lacerda Feio e Newton Dias dos Santos receberam, cada um deles, um voto (CORRÊA, 1997, p. 20).

Com o resultado, lideranças intelectuais tomaram partido. Em carta dirigida ao então Presidente da República, José Linhares, assinada por um vasto círculo de relaçóes intelectuais, seus aliados diziam estar certos de que agiam "em benefício dos mais legítimos interesses da cultura nacional”, e por isso se dirigiam ao Presidente da República: "[...] Pedimos vênia para trazer a Vossa Excelência nosso depoimento a respeito da obra que, na Direção do Museu Nacional, vem realizando a cientista patrícia - professora Heloísa Alberto Torres". Elogiavam as administraçóes de Roquette Pinto e Alberto Betim Paes Leme e de sua digna sucessora. Atentavam para seu esforço na reorganização da instituição e na remodelação do prédio, sob a responsabilidade do SPHAN. Acrescentaram na lista de elogios à diretora os brios com que esta, em face do afastamento da grande maioria dos antigos mestres das ciências naturais e antropólogos, por imposições legais ou aposentadorias, assumiu a difícil tarefa de recompor os quadros gerais do pessoal técnico-científico. Exaltavam a capacidade da "ilustre cientista" em obter a colaboração de várias e significativas instituições nacionais e estrangeiras, garantindo aos jovens pesquisadores bolsas de estudo e outras facilidades de aperfeiçoamento profissional. Enfatizavam na diretora sua

17 Engenheiro de Minas do Ministério da Agricultura, gozando de bom prestígio como mineralogista, foi transferido para o Ministério da Educação e Sáude em 18 de março de 1939, quando tomou posse no Museu Nacional na categoria de naturalista da Divisão de Geologia e Mineralogia. 
larga visão e eficiência, de modo que pediam para que fosse dada à Heloísa a oportunidade de prosseguir no desenvolvimento da obra realizada em benefício da cultura nacional ${ }^{18}$.

Nomes expressivos da cultura brasileira, articulados, sobretudo, por Arthur Mosés, ex-presidente da Academia Brasileira de Ciências, assinavam a carta pública ao Presidente José Linhares em defesa da permanência de Heloísa Alberto Torres na Direção do Museu Nacional, a exemplo de Mário de Brito (Presidente da Academia Brasileira de Ciências), Álvaro Ozório de Almeida (Academia de Ciências e Faculdade Nacional de Filosofia), Roberto Marinho de Azevedo (Escola Nacional de Engenharia), José Carneiro Felipe (Presidente da Comissão Censitária), Afrânio Peixoto (Academia Brasileira de Letras), Guilherme Guinle (Sociedade dos Amigos do Museu), Fernando de Azevedo (Associação Brasileira de Educação), Fernando Romano Milanez (Jardim Botânico), Paulo Parreiras Horta Laclette (Museu Nacional), Cândido Rondon (Presidente do CNPI), Francisco Venâncio Filho (Diretor do Instituto de Educação), Gustavo Mendes de Oliveira Castro (Instituto Oswaldo Cruz), Miguel Ozório de Almeida (Instituto Oswaldo Cruz), Hermes Lima (Escola Nacional de Direito), Iva Waisberg (Instituto de Educação), Alice Flexa Ribeiro (Instituto Anglo-Americano), Fernando de Souza (Diretor do Serviço de Rádio Difusão Educativa do Ministério da Educação e Saúde), Virgílio Moojen de Oliveira, Ana Amélia Queiroz de Mendonça (Presidente da C.E.B.), Gastão Cruls, Carlos Chagas (Faculdade Nacional de Medicina), Maria Eugenia Celso, René Laclette (Faculdade Nacional de Medicina), Ruy Gomes de Moraes (Escola de Medicina e Cirurgia), Delgado de Carvalho (Faculdade Nacional de Filosofia), Vera Roxo Delgado de Carvalho (Presidente da Federação das Bandeirantes do Brasil), Lúcia Miguel Pereira, Octávio Tarquinio de Souza, João Cristóvão Cardoso (Faculdade Nacional

18 Carta ao Presidente da República seguida de abaixo-assinado. Pasta 18. Arquivo Heloísa Alberto Torres, Departamento de Antropologia. Museu Nacional. Também a imprensa fala dessa carta no Jornal Diretrizes, "Intelectuais e cientistas pedem a permanência da Diretora do Museu nacional: um memorial ao Presidente da República - O Museu precisa continuar com a sua obra de desenvolvimento da cultura nacional", datada de 3 I de janeiro de 1946. Pasta "Homenagens", Arquivo CCHAT. Algumas identificações das respectivas filiações institucionais de cada nome não constantes no abaixoassinado foram feitas nas entrevistas. Agradeço especialmente à gentileza do professor Luiz Emygdio de Melo Filho que me possibilitou este trabalho. 
de Filosofia), Joaquim da Costa Ribeiro (Faculdade Nacional de Filosofia), Álvaro Fróes da Fonseca (Faculdade Nacional de Medicina), João Daudt d'Oliveira, Aloísio de Castro. Também apoiaram publicamente Heloísa Alberto Torres: Carlos Drummond de Andrade, chefe do gabinete do ex-Ministro Gustavo Capanema; Joaquim Fernandes Bittencourt de Sá (Divisão Geral do Departamento de Administração do Estado), Rodrigo Melo Franco de Andrade e Gilberto Freyre.

As pressóes para a permanência de Heloísa como diretora do Museu Nacional foram vitoriosas e fizeram com que a nomeação de Othon Leonardos como diretor do Museu, nos primeiros dias de 1946, fosse dada sem efeito. Do ponto de vista legal, a data da eleição havia sido posterior ao decreto que reintegrava o Museu à Universidade do Brasil, sendo, portanto, considerada inválida. Othon Leonardos sentiu-se traído com a decisão, retirando-se do Museu para se tornar assessor da Secretaria Geral do Conselho de Segurança Nacional ao final de 1946, cargo que ocupou até 1956. Heloísa permaneceu na direção da Casa ao fim da luta política, podendo assim terminar a reforma que iniciara.

Apesar da acirrada campanha contra Heloísa, a exposição de Antropologia do Museu Nacional foi reinaugurada em abril de 1947. As 20 salas de exposiçáo da Seção de Antropologia foram reabertas, bem como as salas das divisóes de Zoologia, Botânica, Mineralogia e Geologia. Paschoal Leme (1977, [s. p.]) assim definiu a dedicaçáo de uma vida:

[...] A missão da diretora estava cumprida. Amargurada pelas injustiças que sofrera e cansada pela enorme tarefa que realizara, pouco depois deixava a direção da instituição, onde se formara muito jovem, sob a direção de seu mestre e amigo Roquette Pinto. E passou a integrar o Conselho Nacional do Índio, cujos estudos e defesa eram sua paixão.

Sem se pretender minimizar o trauma de Heloísa, é possível pensar que o sentimento de dever cumprido se sobressaiu ao fim do conturbado período e seus próximos passos demonstraram que a paixáo pela ciência jamais se arrefeceu. A ex-diretora, mantendo suas atividades de naturalista e antropóloga, curiosamente, veio a ser, sem poder então supor, uma das "patrocinadoras" do Cinema Novo quando, em continuidade a suas atividades etnográficas no projeto de Arraial do Cabo, reuniu, em dezembro de 1959, uma equipe de jovens cineastas amadores para 
filmarem o local, dentre eles nada menos que Mário Carneiro, Paulo Cezar Saraceni e Sérgio Montagna ${ }^{19}$.

Heloísa mantinha seu prestígio no campo e, dentre tantas outras responsabilidades em cargos de mando assumidas, devemos igualmente lembrar a Diretoria do Departamento de Estudos e Pesquisas da FUNAI desde a sua instituição, vinculada ao Ministério do Interior através da Lei no 5.371, de 05 de dezembro de 1967, quando extinto o antigo CNPI. No Museu do Índio, que abrigava o departamento, esteve ainda à frente, até dezembro de 1968, do recenseamento nacional das populaçóes indígenas. Trabalhando ininterruptamente pela causa indígena, não era surpreendente que Dona Heloísa demonstrasse uma rara intimidade com os povos ameríndios, somente identificada entre os pesquisadores que com eles viveram, tal como no trabalho que realizou de identificação e sistematização dos filmes da Comissão Rondon a fim de produzir um documentário como parte da Campanha Nacional de Proteção aos Índios, em 1967, o que pude ouvir da então sua jovem assistente, Ana Maria Galano, minha entrevistada em 04 de março de 1999:

De blusa engomada e minúsculos botões de pérola, Dona Heloísa chegava pontualmente à moviola que era abrigada nas dependências da Escola de Desenho Industrial (ESDI). Chegava de jipe com motorista, como para uma expedição por trilhas e florestas. Em pequenas fichas, eu escrevia dados técnicos e comentários de Dona Heloisa sobre grupos indigenas. As fichas iam depois para uma caixa de papelão, embalagem de sapato, na sede da Campanha. Dona Heloisa trabalhou lá até os 73 anos. Com pulso, ela organizou tudo. Ela tinha aquele mapa enorme do Brasil com as tribos todas. Com aquelas cruzinhas todas, as tribos todas marcadas em conjunto. Ela estava sempre recebendo gente, despachando e orientando. Estava sempre trabalhando com essa história das pessoas que ela mandava lá nas expedições. E fazia, e orientava, ela ia seguindo quais as expedições que estavam trabalhando com quais índios.

19 Heloisa conhecia Mário Carneiro desde garoto, sendo ela uma grande amiga do pai, Paulo Carneiro, já no projeto da Hiléia Amazônica. Pediu que o grupo registrasse os hábitos e comportamentos de uma comunidade supostamente protegida dos contatos com a civilização. Em verdade, tal estado de "pureza" não mais existia, mas os jovens viram no projeto uma chance de realizarem seu primeiro filme profissional a partir precisamente da chegada da fábrica de álcalis no local. Dando inteira liberdade ao grupo. Heloisa acabou sendo a responsável pelo filme de curta-metragem brasileiro, um dos marcos do Cinema Novo, o curta Arraial do Cabo, que ganhou seis prêmios internacionais, dentre eles, na Espanha, no Festival de Florença, na Juventude de Roma, assinado por Paulo Cezar Saraceni e Mário Carneiro, e dedicado à Heloísa Alberto Torres, conforme mencionado em Vídeo Brasilianas - MINC-FUNARTE-CTAV. A Mário Carneiro, filho de Paulo Carneiro, agradeço, até hoje, sua simpática e memorável entrevista com a narrativa da "aventura" das filmagens em Arraial do Cabo. 
Frequentemente, era Heloísa também convidada certa nos inúmeros debates sobre a temática para públicos diversos no intuito de divulgar o trabalho de Rondon e as atividades desenvolvidas pelos antigos SPI e CNPI, provavelmente, até quando sua saúde permitiu. A cientista faleceu em 23 de fevereiro de 1977, na casa de Itaboraí, município fluminense, mantendo-se, também viva na memória dos locais, com sua imagem de "ilustre dama, pessoa culta, inteligente, inteiramente voltada para os problemas culturais de nossa terra" ${ }^{20}$.

\section{Considerações finais}

Minha vida foi dura, terrivelmente dura e difícil, mas ainda assim não a trocaria por nenhuma outra. Se eu tivesse que recomeçar, seria para ser o que sou, como sou.

(Heloísa Alberto Torres, 0 diário de notícias, 06 de fevereiro de 1952).

Foi realmente uma vida dura para uma mulher, nascida em 1895 e falecida em 1977, no Brasil. Solteira, sem filhos e ocupante de cargos públicos que a colocaram, contínuas vezes, acima de homens também de ciência e de poder. Sua única familiar próxima era a irmã, também solteira, com quem morava. A herança do nome do pai jamais teria bastado para a realização de uma carreira táo excepcional, longa, estável e bem-sucedida. Soube, certamente, usufruir de seu formidável capital cultural e trabalhar, tanto quando ou mais do que qualquer homem, para não ceder às adversidades. Era infatigável em sua capacidade gerencial e disposiçâao para as alianças com os homens que com ela pudessem levar avante ideais comuns. Sua causa era nacional: a Antropologia à qual se dedicou tornava-se, em seu contexto, prática científica e lócus de enunciação da brasilidade, pautando o debate público sobre a preservaçáo das culturas e a promoção da identidade nacional.

Um projeto de vida, tal como explicita Gilberto Velho (1994, p. 101), é a conduta organizada para atingir finalidades específicas que náo podem ser conhecidas no início da trajetória do indivíduo, mas se tornam claras a

20 Moção de pesar requerida pelo vereador Fabiano Barros, da Câmara Municipal de Itaboraí, em primeiro de março de 1977, ao Plenário da Câmara pelo falecimento de Heloísa Alberto Torres. Arquivo da Casa de Cultura Heloisa Alberto Torres. 
posteriori, no processo de sua avaliação, através dos recursos da memória e da biografia, que sugerem uma visão retrospectiva dos acontecimentos. É possível afirmar que uma das conquistas do indivíduo moderno é a expansão de seu arbítrio sobre seu projeto de vida, mas isto está muito longe de significar que qualquer um de nós tenha efetivamente o poder de decisão sobre sua história.

Nesse sentido, Pierre Bourdieu (1986, p. 69-72) alerta-nos quanto à ilusão biográfica, quando se passa a examinar uma vida sem percebê-la "[...] como colocaçóes e deslocamentos no espaço social, nos diferentes estados sucessivos da estrutura da distribuição das diferentes espécies de capital que estão em jogo no campo considerado”. Para Bourdieu, uma trajetória de vida torna-se inverossímil ou simplesmente irrelevante quando se despreza o conjunto de relaçóes objetivas que unem o agente considerado ao conjunto dos outros agentes envolvidos no mesmo campo e confrontados com o mesmo espaço dos possíveis.

Trazemos, novamente, Williams (2011) para quem a "estrutura de sentimentos" - tipo de articulação que expressa um universo real compartilhado de expectativas e necessidades, fluxos de inter-relação entre grupos, espaços e temporalidades, chamado, também, de mood, clima, atmosfera, humores - aponta para os elementos externos e internos às pessoas e aos grupos que, como uma "tonalidade contextual" sempre em mutação, contagiando todos.

Estamos então definindo esses elementos como uma "estrutura": como uma série, com relações internas específicas, ao mesmo tempo engrenadas e em tensão. Não obstante, estamos também definindo uma experiência social que está ainda em processo, com freqüência [sic] ainda não reconhecida como social, mas como privada, idiossincrática, e mesmo isolada, mas que na análise (e raramente de outro modo) tem suas características emergentes, relacionadoras e dominantes e na verdade suas hierarquias específicas. (WILLIAMS, 1979, p. 134).

Nesse caso, a biografia se dá em uma "estrutura de sentimentos" que é, por excelência, uma constelação de interações. Retomamos, neste momento, a sociologia relacional de Georg Simmel (1939) a fim de poder melhor enxergar a dinâmica dos círculos sociais, dos indivíduos nestes e dos círculos sociais nos indivíduos, atentando para o movimento, mais perceptível ou menos, no cotidiano que fazem pessoas se tornarem quem se tornam, 
como efeito de uma mutualidade de afetaçôes, ao mesmo tempo em que afetam o mundo e produzem socialmente algo. Em minha investigação, a personalidade de Heloísa é fruto, dentre outros, das ambiências culturais que experimentou, assim como estas, mais precisamente as ciências sociais e a pesquisa antropológica no Brasil, são produtos das interaçôes das quais Heloísa participou como uma das protagonistas.

Todas as milhares de relações, de pessoa a pessoa, momentâneas ou duradouras, conscientes ou inconscientes, mais consequentes ou não, atam-nos incessantemente, e isto é o que se chama sociedade. Como puxando os fios de uma tapeçaria, a vida de Heloísa leva-nos a descortinar um Brasil que lutava, em consonância ao ideal positivista, por seu progresso científico indossociável do desenvolvimento econômico, ao mesmo tempo em que se sensibilizava para as culturas da terra como ícones da identidade nacional. Falamos do empenho modernizador da era Vargas e do papel dos museus neste, uma vez situados na tensão entre o passado e o futuro para projetar uma naçáo.

No cotidiano do Museu Nacional, deu-se a emergência e a consolidação de um tipo específico de Antropologia, na criação da rotina da ciência e do trabalho intelectual no Brasil. Isto implica a construção de novos círculos sociais, hierarquias, grupos e instituiçóes, em constantes rearranjos motivados por conflitos, adaptaçôes, insurgências, recuos, reposicionamentos. O olhar microscópico de inspiração simmeliana, assim como a percepção trazida pelo materialismo cultural de Raymond Williams, ajudou-nos a evidenciar os aspectos concretos, porém, menos formais da vida social, que nos permitem apreender as experiências sociais em solução ainda quando em circunstâncias que aparentam uma paralisia mas não imobilizam; por isso, as possibilidades de inéditas interaçóes.

Relembrar a presença de Heloísa Alberto Torres no Museu Nacional e na história da Ciência e da Antropologia no Brasil é dizer que há um acúmulo de trabalho e reflexão transgeracional que não se perde completamente sequer em momentos desoladores. Ao lado das descontinuidades percebidas, há continuidades se nosso foco estiver mais nos desempenhos de pessoas e grupos que sobrevivem ainda quando as instituiçóes se fragilizam ou desaparecem. 
Por fim, falar de Heloísa é falar do desempenho de mulheres. Neste caso, uma mulher tornada figura-chave na manutenção e na transmissão de um legado, responsável pelo treinamento de novos quadros profissionais, pela provisão de um ambiente adequado ao aprendizado, pela sustentação de padrôes de qualidade para a internacionalização da ciência no Brasil, em um tempo em que as funçóes públicas eram conjugadas apenas no masculino. Dar visibilidade, portanto, à participação de algumas poucas mulheres nos momentos germinais da criação de um campo do saber é lhes fazer justiça ao mesmo tempo em que é melhor compreender o projeto das ciências sociais brasileiras.

Sobretudo, se o conceito de sociedade somente existe como processo, o que faz a sociedade existir são as relaçóes que se estabelecem ininterruptamente entre os indivíduos. Náo seria diferente quando se tenta explicar a consolidação de um campo de conhecimento. Desse modo, cabe afirmar que os começos sempre se renovam a cada aparente fim - como no exemplo do incêndio do Museu Nacional. Novas geraçóes sucedem as anteriores e assumem o protagonismo histórico, quiçá inspiradas no que de melhor seus antecessores puderam fazer, e seguem abrindo possibilidades até então desconhecidas.

\section{Referências}

\section{A) Livros, capítulos de livros e artigos}

ÁVILA, B. de. No pacoval de Carimbé. Rio de Janeiro: Calvino Filho Ed., 1933.

AZEVEDO, F. de. As Ciências no Brasil. V. 2. Rio de Janeiro, Ed. UFRJ, 1994.

BOURDIEU, P. A ilusão biográfica. In: MORAES FERREIRA, M. de; AMADO, J. (Org.). Usos e abusos da história oral. Rio de Janeiro: FGV, 1996. p. 183-191.

CARVALHO, José C. Museu Nacional. Boletim do Conselho Federal de Cultura, v. 28, jul.-set. 1977.

CASTRO FARIA, L. de C. Antropologia - escritos exumados, espaços circunscritos, tempos soltos - 1. Rio de Janeiro: EDUFF, 1998.

CORREAA, M. Dona Heloísa e a pesquisa de campo. Revista de Antropologia, São Paulo, v. 40, n. 1, p. 11-54, 1997.

DOMINGUES, H. B. Heloísa Alberto Torres e o inquérito nacional sobre ciências naturais e antropológicas. Bol. Mus. Pará Emílio Goeldi, Belém, v. 5, n. 3, p. 625-643, set./dez. 2010. 
DOMINGUES, H. B. As ciências naturais e construção da nação brasileira. Revista de História, São Paulo, v. 135, n. 2, p. 41-59, 1996.

FREYRE, G. Casa grande \& senzala: formação da família brasileira sob o regime da economia patriarcal. 52. ed. (edição comemorativa). São Paulo: Global, 2013.

GONDRA, J. G.; SCHUELER, A. Educaçáo, poder e sociedade no Império Brasileiro. São Paulo: Cortez, 2008.

LEMOS, M. T. B. Alberto Torres: contribuição para o estudo das idéias no Brasil. Rio de Janeiro: Quartet e Comunicação, 1995.

LOPES, M. M. O Brasil descobre a pesquisa científica: os museus e as ciências naturais no século XIX. São Paulo: HUCITEC, 1997.

MAIO, M. C.; SÁ, M. R. Ciência na periferia: a Unesco, a proposta de criação do Instituto Internacional da Hiléia Amazônica e as origens do Inpa. História, Ciência, Saúde, Manguinhos, Rio de Janeiro, v. 6, p. 975-1017, set. 2000. Disponível em: http://www.scielo.br/scielo.php?script=sci_ arttext\&pid=S0104-59702000000500011\&lng=en\&nrm=iso. Acesso em: 2 nov. 2018.

MASSI, F. Franceses e norte-americanos nas ciências sociais brasileiras (1930-1960). In: MICELI, S. (Org.). História das ciências sociais no Brasil. V. 1. São Paulo: Vértice/IDESP, 1989. p. 478-531.

MiglieVICH-RIBEIRO, A. M. Heloísa Alberto Torres e Marina Sáo Paulo de Vasconcelos: entrelaçamentos de círculos e formação das ciências sociais na cidade do Rio de Janeiro. Rio de Janeiro: UFRJ/IFCS, 2000.

MIGLIEVICH-RIBEIRO, A. M. Heloísa Alberto Torres e Marina de Vasconcellos: pioneiras na formação das ciências sociais no Rio de Janeiro. Rio de Janeiro: Editora UFRJ, 2015.

MIGLIEVICH-RIBEIRO, A. M. Darcy Ribeiro e Utopia no Exílio LatinoAmericano: "Estruturas de Sentimentos” como Hipótese Metodológica. Revista Tomo, São Cristóvão, Sergipe, n. 32, p. 15-40, jan./jun. 2018.

QUEIROZ, M. I. P. de. Desenvolvimento das Ciências Sociais na América Latina e contribuição européia: o caso brasileiro. Ciência e Cultura (SBPC), v. 41, n. 4, p. 378-388, $2^{\circ}$ sem. 1997.

ROQUETTE PINTO, E. Rondônia. São Paulo, Rio de Janeiro, Recife, Porto Alegre: Companhia Editora Nacional, 1938.

SCHWARCZ, L. Os institutos históricos e geográficos. Os guardiôes de nossa história oficial. São Paulo: Editora Vértice/Idesp, 1989.

SIMMEL, G. Sociología: estudios sobre las formas de socialización. Buenos Aires: Espasa-Calpe, 1939.

VELHO, G. Projeto e metamorfose: antropologia das sociedades complexas. Rio de Janeiro: Jorge Zahar Ed., 1994.

WEBER, M. Economía y Sociedad. V. 2. México: Fondo de Cultura Económica, 1944. 
WEBER, M. Economia e Sociedade. Vol. 1. Brasília: EdUnB, 1991.

WILLIAMS, R. Cultura e materialismo. São Paulo: Ed. Unesp, 2011.

\section{B) Arquivos e documentos}

Arquivo CCHAT

Sala de Memória da CCHAT:

Pasta 045 "Documentos"

TORRES, H. A. T. Livreto Cerâmica de Marajó - registro da conferência proferida por Heloísa Alberto Torres na Escola Nacional de Belas Artes. Rio de Janeiro: Ed. Typ Brasil Social Humaytá, 1929. (Série Salão).

Arquivo "Heloísa Alberto Torres"

Pasta "Homenagens":

Impresso - ABC, 12 de setembro de 1925 - "Lugar à cultura e à inteligência da mulher!".

Impresso - Diretrizes, 31 de janeiro de 1946 - "Intelectuais e cientistas pedem a permanência da Diretora do Museu Nacional: um memorial ao Presidente da República - O Museu precisa continuar com a sua obra de desenvolvimento da cultura nacional”.

Impresso - Diário de Notícias, quarta-feira, 06 de fevereiro de 1952 - "Mulheres contam a sua vida (XVII): com a Diretora do Museu Nacional - Heloísa Alberto Torres trabalha e constrói... a Diretora infatigável”.

Moção de pesar requerida pelo vereador Fabiano Barros, da Câmara Municipal de ltaboraí, em primeiro de março de 1977, ao Plenário da Câmara pelo falecimento de Heloísa Alberto Torres.

Caderno avulso: POURCHET, M. J. Heloísa Alberto Torres (1895-1977). 1977.

Carta de Paschoal Leme para O Globo, 13 de março de 1977.

Pasta "Correspondências":

Carta de Gilberto Freyre, datada de 09 de maio de 1930.

Pasta 18:

Carta ao Presidente da República José Linhares seguida de abaixo-assinado.

Memorial de HAT, 21 de dezembro de 1945. Pasta 18. Arquivo Heloísa Alberto Torres, Departamento de Antropologia, Museu Nacional.

\section{C) Entrevistas realizadas (em ordem alfabética):}

Ana Maria Galano - 04/03/1999.

Lygia Martins Costa - 09/03/1998. 
Luiz de Castro Faria - 18/03/1999.

Sólon Leontsines - 16/03/1999.

\section{Revisiting the National Museum and the History of Anthropology in Brazil by Heloísa Alberto Torres}

\section{Abstract}

The article highlights Heloísa Alberto ( 1895-1977)'s leading role in the field of science and culture in Brazil, in her role as an anthropologist and director of the National Museum, the guardian institution of the largest collections in Natural History and Anthropology. The analysis of its trajectory allows the reconstruction of the "social circles", in their intersections and tensions, that enabled, in the Vargas Era, the formation of important Brazilian institutions committed to the construction of the national identity. In a special "structure of feelings" marked by positivism and the inherence between scientific progress and economic development, Heloísa Alberto Torres's struggle reveals the appreciation of natural wealth and primary cultures as an outsdanding feature of the anthropological field in the early stages. The visibility of the scientist's exceptional trajectory also seeks to do justice to those women who acted in public life, in positions of command, at a time when science was still an exclusively male domain. Finally, we conclude that the dynamics of social life and historical changes on the immobility of institutions are prevalent so that even in the most hostile scenarios it is possible to identify the emergencies that keep hope alive.

Keywords: Heloísa Alberto Torres. National Museum. History of Anthropology.

Recebido em: 02/11/2018

Aprovado em: 03/04/2019 